\title{
(बR
}

\section{Metoclopramide Induced Acute Dystonic Reaction in a Child: A Case Report}

\author{
Bir Çocukta Metaklopramid'e Bag̃lı Akut Distonik Reaksiyon: Bir Olgu Sunumu
}

Sedat Ișıkay, Mehmet Almacıog̃lu, Kutluhan Yılmaz

Department of Pediatrics, Faculty of Medicine, Gaziantep University, Gaziantep, Turkey

\section{ABSTRACT}

Metoclopramide is a dopamine receptor antagonist drug that has been used for treatment of a variety of gastrointestinal symptoms. It may also cause a variety of extrapyramidal movement disorders. Acute dystonia is a rare side effect that develops especially in children within the $1^{\text {st }} 3^{\text {rd }}$ days of metoclopramide treatment. Acute dystonias usually present themselves as buccolingual, torticollic, oculogyric, tortipelvic, and/or opisthotonic forms. A seven-yearold boy was referred to our emergency department from another hospital with the pre-diagnosis of seizure. A diagnosis of acute gastroenteritis had been made there and treatment with intravenous fluid and metoclopramide $(0.5 \mathrm{mg} / \mathrm{kg}$ per day in three doses) had been started two days prior. One hour earlier, atypical limb and head movements had begun and seizure was thought to be the cause. Consequently, he was sent to our department for further evaluation. Based on the history and physical examination findings, a diagnosis of acute dystonic reaction was made and biperidene lactate ( $5 \mathrm{mg}$ ) was given. Four hours later, all symptoms had abated. In conclusion, acute dystonic reactions developing due to metoclopramide can be confused with seizures, because of physicians' unfamiliarity with dystonic movements. Therefore, it is necessary that acute dystonic reactions be considered in differential diagnosis of seizures.

Keywords: Adverse effects, dystonic reactions, metoclopramide, child

Received: 06.05.2011 Accepted: 13.06.2011

\section{ÖZET}

Metoklopramid çeșitli gastrointestinal semptomların tedavisinde kullanılan dopamin reseptör antagonisti olan bir ilaçtır. Bu ilaç çeșitli ekstrapiramidal hareket bozuklug̃una neden olabilmektedir. Metoklopramid tedavisinin 1.-3. günlerinde nadir bir komplikasyon olan akut distoni gelișmektedir. Akut distoniler genellikle bukkolingual, tortikollik, okülojirik, tortipelvik ve/veya opistotonik șekillerde olmaktadır. Yedi yașında erkek olgu, bașka bir hastaneden nöbet öntanısı ile acil klinig̃ine refere edilmiști. Hastaya geldig̃i hastanede iki gün önce akut gastroenterit tanısı konulmuş ve damardan sıvı ve metoklopramid $(0.5 \mathrm{mg} / \mathrm{kg} / \mathrm{gün}, 3 \mathrm{dozda})$ tedavileri bașlanmıștı. Bir saat önce vücudunda, ekstremitelerinde ve kafasında atipik hareketler olmaya bașlamış, nöbet düşünülmüștü. Bu yüzden olgu ileri tetkik için sevk edilmiști. Öykü ve fizik muayene bulguları ile akut distonik reaksiyon tanısı konulan olguya biperidene lactate $(5 \mathrm{mg}$ ) verildi. Dört saat sonra tüm semptomları iyilești. Sonuç olarak, metoklopramide bag̃lı gelișen akut distonik reaksiyonlar, hekimler tarafından distonik hareketlerin sıklıkla iyi bilinmemesinden dolayı nöbetler ile karıștıılabilir. Bu yüzden, biz akut distonik reaksiyonların nöbet ayırıcı tanısında düşünülmesi gerektig̃ini vurguluyoruz.

Anahtar Kelimeler: Yan etkiler, distonik reaksiyonlar, metoklopramid, çocuk

Geliş Tarihi: 06.05.2011 Kabul Tarihi: 13.06.2011

\section{Introduction}

Metoclopramide is a central and peripheral dopamine antagonist that is usually prescribed to children as an antiemetic agent. It is used most commonly for the treatment of gastroesophageal reflux disease, gastroenteritis, and chemotherapy-induced nausea and vomiting. Extrapyramidal reactions are rarely seen side effects of metoclopramide. Acute dystonic reactions can be observed even at minimal dosage level. Within 24-72 hours after taking this medicine, some indications might include spasms of the neck, back and facial muscles, torticollis, oculogyric crisis, grimacing, dysarthria, trismus and akathisia. The observation of amnesia and typical clinical signs is sufficient for diagnosis (1-6). The present study introduces a case in which an acute dystonic 
reaction was observed following the usage of metoclopramide. This case emphasizes that the side effects of this medicine, which is prescribed frequently by physicians, should be carefully considered.

\section{Case Report}

A case of a seven-year-old boy with contractions of the muscles, primarily of the neck, back, chin, arms; bending of his neck and head; dyslogia; and deviation of the eyes was brought to our emergency polyclinic by his parents. Two days previously, because of his complaints about diarrhea and vomiting, he had been hospitalized and the treatment of intravenous fluid and $(0.5 \mathrm{mg} / \mathrm{kg} /$ day, three doses) metoclopramide was administered. His records indicated that his complaints decreased. However, one hour before admission to our hospital, contractions and pain in his neck started and these complaints increased over time. With the suspicion of seizure, phenytoin was administered to the patient. No special medical circumstances were noted regarding his situation and background. On physical examination, his arterial blood pressure was $110 / 70 \mathrm{mmHg}$, pulse was 76 beats/min, respiratory rate was 16 breaths/min, and axillary temperature was $37^{\circ} \mathrm{C}$. The patient showed a normal level of consciousness, but had coordinated and patterned movements and dystonia in his hands and legs; torticollis in his neck; oculogyric crisis, and atypical buccolingual movements (Figure 1). The case was diagnosed as metoclopramide induced acute dystonic reaction because complementary symptoms were acute and the patient had a history of metoclopramide administration. Metoclopramide treatment was stopped and he was given $5 \mathrm{mg}$ biperidene lactate intravenously. Four hours later, all his symptoms had disappeared. The symptoms did not occur again. He was called for a control visit 2 days later. A repeated physical examination at the control visit was completely normal.

\section{Discussion}

Metoclopramide is widely administered in infants and children, especially by the physicians working in emergency services, for the treatment of respiratory tract infections and gastroenteritis-induced vomiting. The primary indication in the preoperative phrase is to reduce gastric contents and to increase lower oesophageal sphincter tone for pharmacologic pulmonary aspiration prophylaxis. Metoclopramide can precipitate extrapyramidal symptoms such as druginduced movement disorders. The anti-emetic effects of metoclopramide result from inhibition of $\mathrm{D} 2$ and $5-\mathrm{HT} 3$ receptors within the chemoreceptor trigger zone. These effects caused by the medicine are not dose related; they present as idiosyncratic. Thus, side-effects can develop even with the treatment doses. The side-effects can be seen more commonly when the doses are higher than the recommended doses. With repeated doses, a cumulative effect is observed (1-4).

Without a good history, diagnosis of dystonia caused by metoclopramide is difficult, as symptoms can be confused with other diseases such as seizure and encephalopathy. Extrapyramidal reactions are the most commonly manifested acute side effects, and these include dystonia (contractions of the muscles; primarily of the face, neck and back; opisthotonos, torticollis, oculogyric crisis, facial gri-

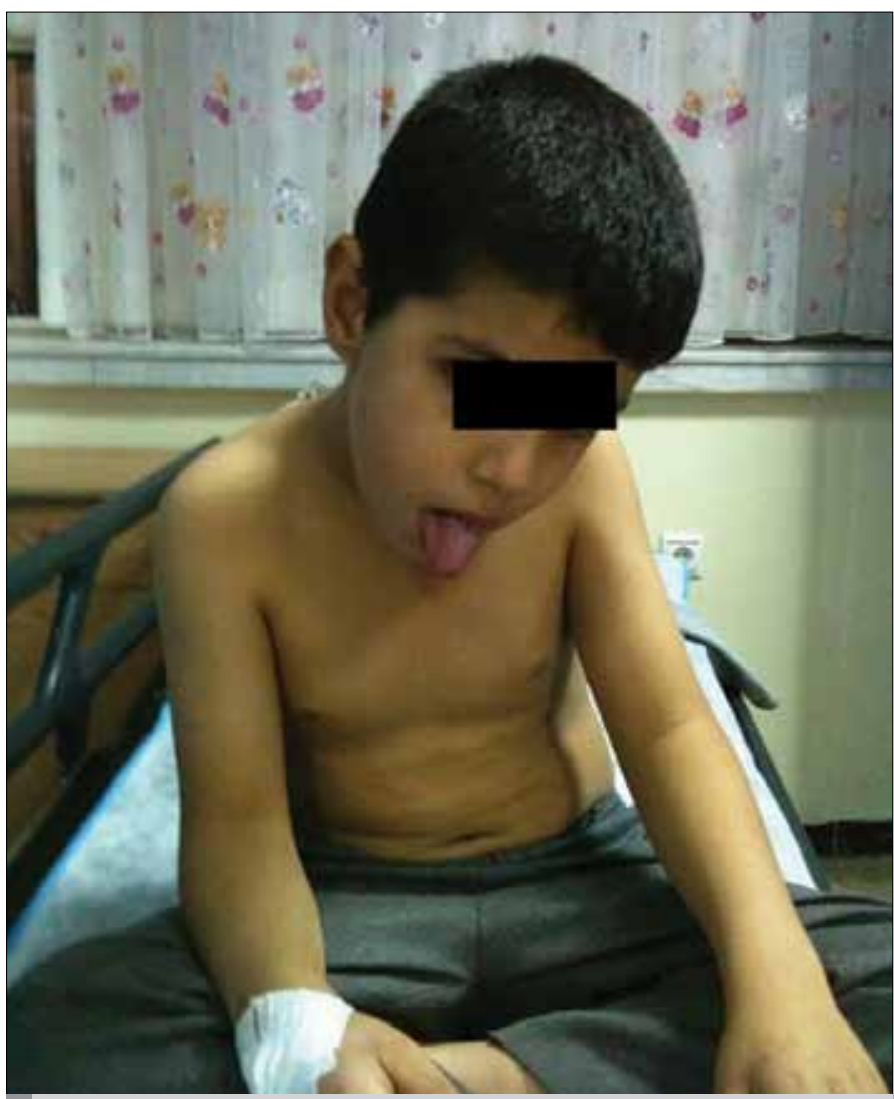

Figure 1. The dystonic facial appearance of the patient

macing, dysarthria, and trismus), akathisia, and Parkinsonism (3-6). Two cases presented by Yis et al. (3) had been first diagnosed as encephalitis and atypical pneumonia, but with the knowledge of the medicine prescribed in their history, an acute dystonic reaction caused by metoclopramide was ultimately diagnosed.

In the table of metoclopramide induced acute dystonic reactions, diphenhydramine hydrochloride $(1.25 \mathrm{mg} / \mathrm{kg} / \mathrm{dose}$, oral, injection in vein or muscle, 6-hour periods, maximum 300 mg/day), biperidene lactate $(0.04 \mathrm{mg} / \mathrm{kg}$, oral, injection in vein or muscle, 30-minute periods, maximum 4 doses), and benztropine mesylate (0.02-0.05 $\mathrm{mg} / \mathrm{kg} /$ dose) oral, injection in a vein or muscle, 1-2 times in a day, (maximum $2 \mathrm{mg} /$ day) are suggested as treatments (4). In the present case, the side-effects of metoclopramide were observed between the $48^{\text {th }}$ and $72^{\text {nd }}$ hour at therapeutic doses. The case was not initially differentiated from seizure because the original physicians were not able to identify the symptoms and the patient was referred to our clinic. Subsequently, based on the sudden inception of signs, the existence of dystonic symptoms, the swift improvement, the history of metoclopramide administration, the quick response to biperidene lactate, and the patient having a good medical history, metoclopramide induced acute dystonic reactions was readily diagnosed.

\section{Conclusion}

Scientific documentation confirms that metoclopramide treatment can cause acute dystonic reactions. Thus, a diagnosis of dystonia, 
which is a movement disorder, requires a detailed examination of the prior treatment history of patients at emergency clinics.

\section{Conflict of interest}

No conflict of interest was declared by the authors.

\section{References}

1. Dipalma JR. Metoclopramide: a dopamine receptor antagonist. Am Fam Physician 1990; 41: 919-24.

2. Moos DD, Hansen DJ. Metoclopramide and extrapyramidal symptoms: a case report. J Perianesth Nurs 2008; 23: 292-9. [CrossRef]
3. Yis U, Ozdemir D, Duman M, Unal N. Metoclopramide induced dystonia in children: two case reports. Eur J Emerg Med 2005; 12: 117-9. [CrossRef]

4. Yarar Ç. Zehirlenme ve Illaçlara Bag̃lı Gelișen Nörolojik Hastalıklar. In Gökçay E, Sönmez M, Topalog̃lu H, Tekgül H, Gürer YKY, Editors. Çocuk Nörolojisi. 2nd ed. Ankara: Anıl Grup Matbaacılık; 2010. P.577-87.

5. Grimes JD, Hassan MN, Preston DN. Adverse neurologic effects of metoclopramide. Can Med Assoc J 1982; 26: 23-5.

6. Miller LG, Jankovic J. Metoclopramide-induced movement disor $\neg$ ders. Clinical findings with a review of the literature. Arch Intern Med 1989; 149: 2486-92. [CrossRef] 